Владимир Гильманов, Леонид Мальцев

Балтийский федеральный университет имени Иммануила Канта

lamaltsev23@mail.ru

Vladimir Gil'manov, Leonid Mal'tsev

Immanuel Kant Baltic Federal University

lamaltsev23@mail.ru

\title{
МЕТАФИЗИКА ГОРОДСКОГО ПРОСТРАНСТВА В РОМАНЕ П. ХЮЛЛЕ ВОСПОЙ САДЫ
}

\author{
METAPHYSICS OF THE URBAN SPACE \\ IN PAWEL HUELLE'S NOVEL SING THE GARDENS
}

Анализируется художественное пространство городского текста на примере романа Павла Хюлле Bocnoŭ cadbl. Определяется система локусов города в аспекте противостояния «польскости» и «немецкости» Гданьска - Данцига. Подчеркивается также значение фактора этнической идентичности кашубов в художественной презентации пространства города. Утверждается, что палимпсестная организация городского текста Хюлле выходит за рамки оппозиции польское - немецкое и базируется на представлениях о полиэтничности и поликультурности Гданьска. Делается вывод о том, что центральным мифообразующим топосом является сад, смысл которого заключается в преодолении отчужденности пространства.

Ключевые слова: Хюлле, пространство, город, «гданьский текст», карта, топос сада, палимпсест, экстерриториальность.

The paper analyzes the artistic space of the "Gdansk text" on the example of Pawel Huelle's novel Sing the Gardens. The paper confirms that the analyzed novel belongs to the direction of "local homelands" in Polish literature. We demonstrate the significance of the landscape map as a basic instrument used in constructing the artistic space. We define the system of town locus from the aspect of juxtaposing the "Polish" and "German" Gdansk - Danzig and the spatial expression of this historical conflict. We also emphasize the importance of the factor of national identity of the Kashubs in the artistic representation of the urban space. Accordingly, we notice that the palimpsest organization of Huelle's urban text goes beyond the framework of the Polish-German opposition and that it is based on the representations of polyethnicity and polyculturality of Gdansk, in whose history the Kashubs, Prussians and many others played an important role. We conclude that the central peace-making topos of storytelling is the garden, which makes sense of processing and conquering nature and overcoming the 
alienation of space. On the other hand, we emphasize that the nature of the garden in Huelle's novel is ambivalent since it is not only the topos of creation but also the topos of the apocalypse.

Key words: Huelle, space, town, "Gdansk text", map, topos of garden, palimpsest, ex-territoriality.

\section{1. Введение}

Павел Хюлле (родился в 1957 году в Гданьске) — один из представителей направления «малых родин» в новейшей польской литературе (см. об этом направлении следующие работы: (Olejniczak 1992; Przybylski 1994)), наряду с Ольгой Токарчук, Анджеем Стасюком, Стефаном Хвином, Александром Юревичем и многими другими прозаиками. Основополагающую роль в литературе «малых родин», называемой также «литературой места» или «литературой локального тождества», играет категория пространства, а ключевыми образами становятся карты местности, города, региона. Причину интереса к картографии в современной польской литературе определяет 3. Зёнтек: «В мире ускоренных видоизменений, исторических катаклизмов, перемещений огромных человеческих масс и меняющихся границ оно (пространство - В. Г., Л. М.) было проявлением тоски обо всем устойчивом, что можно противопоставить всепоглощающему хаосу» (Ziątek 1998: 321)1.

Выдвигая тезис о «геопоэтическом повороте» современных гуманитарных исследований, Э. Рыбицкая, в свою очередь, полагает, что выражением пространственной модели мира-космоса, противостоящего современному миру-хаосу, является карта, трактуемая не только как «нейтральное средство визуализации географический данных», но и как инструмент «топографической герменевтики (Карл Шлёгель)», исполняющий важную аксиологическую функцию, поскольку «карты, представленные в литературе последних лет, являются метафорическим местом памяти, своего рода мнемотопосом, напоминающим о прошлом конкретного пространства» (Rybicka 2014:151-152). Следуя традициям классика польской литературы XX века Бруно Шульца, создавшего в рассказе «Улица Крокодилов» образ карты родного городка Дрогобыча, Хюлле с таким же энтузиазмом пишет о точной карте Гданьска и окрестностей как о «мечте детства» (Huelle 2016: 251) и заветной «идее» (Huelle 2016: 253), связывающей автора с семейным и культурно-историческим прошлым. В сознании Хюлле карта является импульсом мифологизации действительности: именно так писатель воспринимает карту Восточных кресов, доставшуюся в наследство от деда («Эти большие, подшитые тканью листы, пахнущие войной, охотой и приключениями, разложенные при вечернем свете лампы, вели в иной мир» (Huelle 2016: 251)).

1 Перевод с польского здесь и далее В. Г., Л. М. 
В хронотопической структуре прозы Хюлле ведущую роль играет топографически конкретная образность, посредством которой раскрывается историческая, природная и культурная самобытность Гданьска. В романе Вайзер Давидек (1987) автор пишет о «картографической точности» (Huelle 1987: 98) как неотъемлемом элементе мифопоэтического мировосприятия города. В романе Восnой сады (2014) Павел Хюлле также реализует идею органического синтеза художественного мифологизма и биографической достоверности образов («История вступала в мои любимую область вымысла, которая, прежде чем стать повествованием, брала свое начало в реальных событиях» (Huelle 2014: 8)). В прозе Хюлле события разворачиваются топографическом пространстве точно указанных домов и улиц, хотя иногда эта точность является мистификационным приемом. Происходит хаотизация топографического космоса и открывается эсхатологическая реальность, в которой через прошлое отдельно взятого города просматривается трагическая судьба мировой истории.

\section{2. Художественная топография «гданьского текста» П. Хюлле}

Исследование городского текста является одной из актуальных проблем современного литературоведения. Наряду с «петербургским», «московским», а также текстами многих других городов, существует «гданьский текст», представленный творчеством Гюнтера Грасса, Стефана Хвина, Павла Хюлле. В исследовании романа Хюлле Вайзер Давидек «гданьский текст» осмыслен как «семиотический интеграл, позволяющий соотнести реальный топографический план, отраженный в немецко-польской топонимике Данцига-Гданьска, с планом скрытых мифоисторических аллюзий и коннотаций» (Копцев - Мальцев 2018: 103). Как и Вайзер Давидек, роман Восnой сады входит в прозаический цикл о Гданьске, ключом к хронотопу которого является карта города. «Сквозным» локусом в презентации пространства города играет аллея Грюнвальдская (нем. Hauptallee) - коммуникационная магистраль, соединяющая исторический центр Данцига-Гданьска с районами Вжещ (Langfuhr) и Олива. В свою очередь, старейшая коммуникация, соединяющая районы Вжещ и Олива - улица Полянки (Pelonkerweg). Все указанные локусы являются значимыми точками на художественной карте города. Например, в романе Вайзер Давидек основные события происходят на западной окраине Вжеща - Лангфура под названием Стшижа Гурна (Hochstrieß) и в расположенном к югу от Стшижи районе Брентово (Brentau). Центральный локус романа Восnой сaдbl - старинный двор на улице Полянки, соседствующий с «двором Шопенгауэров».

Хронотоп анализируемого нами романа Восnой сады определяется дистанцией между заброшенным домом на Полянке, где живет храни- 
тельница довоенного прошлого Данцига Грета Хофман-Винтерхаус, и домом на улице Хшановского в Стшиже как местом жительства юного рассказчика с родителями. Рассказчик хранит предание о том, как в 1945 году его отец впервые ступил на гданьскую «землю обетованную» (Huelle 2014: 16), поселившись в доме на улице Полянки. Переселение оттуда на улицу Хшановского символизирует психологический разрыв польской семьи с немецким прошлым. Впервые этот рубежный факт биографии писатель художественно осмыслил в рассказе «Переезд» (1987), который является ранним наброском романа «Воспой сады».

Происходит отчуждение Греты от окружения, что связано с тяжелой памятью о войне, недоверием и подозрительностью поляков по отношению ко всему немецкому. Психологическую и пространственную дистанцию между «польскостью» и «немецкостью» акцентирует в момент переселения мать героя-рассказчика: «Подальше от этой немчуры (Niemry - В. Г., Л. M.)» (Huelle 2014: 6), а отец для того, чтобы вызвать у сына недоверие к немцам, рассказывает случай из партизанского прошлого, когда его чуть не убил немецкий солдат («Ведь так нас называли — polnische Banditen, об этом никогда не забывай — polnische Banditen - повторил он с каким-то страданием в голосе» (Huelle 2014: 124)). Однако принадлежащий младшему поколению герой-рассказчик тайком от родителей постоянно навещает одинокую жительницу дома на Полянке, чтобы слушать ее рассказы о прошлом, испытывая сопереживание к лучшим представителям немецкого народа, жизнь которых была сломана преступлениями фашизма.

В ретроспекции Греты дом на улице Полянки как место счастливой любви Греты и ее мужа композитора Эрнста Теодора Хофмана ${ }^{2}$ сюжетно связан с лесной оперой (Waldopera) в Сопоте, в которой состоялось знакомство героев романа. Между домом на Полянке и сопотской лесной оперой находится один из наиболее значимых сентиментальных локусов романа Хюлле - Оливский парк как место встречи Райнера Мария Рильке с Лу Саломе в 1898 г. Эта встреча в Оливе играет большую роль в творческих исканиях Эрнста Теодора. Композитор, наделенный изобразительным талантом, проводит параллель между своей любовью и любовью Рильке («...ведь Лу - это была она, Грета, ее лицо, а поэтом был он сам» (Huelle 2014: 175)).

Если дом на улице Хшановского в сознании героя-рассказчика представляет собой воплощение «польскости» послевоенного Гданьска, а дом на Полянке - воплощение «немецкости» довоенного Данцига, то «хата» («czecza») в Ребмехово (нем. Ramkau) пана Бешка («Бешк или Бешка,

2 Практически полное совпадение имени и фамилии героя с классиком немецкой литературы вызвано, по сюжету романа, решением отца, отметившего факт связи с Данцигом творчества их знаменитого однофамильца как автора рассказа «Двор Артуса» (1816). 
но наверняка не Бещаньский» [Huelle 2014: 5, 318), связана с автохтонным народом Гданьска - кашубами. «Образ пана Бешка, - говорит писатель, - это мой поклон кашубской культуре, которую я очень ценю и среди которой я в определенном смысле был воспитан» (Huelle, Szczepuła 2014). Гений места, пан Бешк находится между разделенными и противопоставленными друг другу мирами «польскости» и «немецкости». Эта роль символически подчеркивается работой Бешка в качестве извозчика: на его телеге осуществляется переезд семейства рассказчика с улицы Полянки на Хшановского. Мифологическая функция Харона как последнего посредника между утратившими связь мирами закрепляется за паном Бешком уже в первом предложении: «Спустя годы я вижу его шершавые ладони, которые держали не весло, а вожжи двуконной упряжи, но, несмотря на эту разницу, пан Бешк выплывает из страны воспоминаний не только как перевозчик из одного района города в другой» (Huelle 2014: 5).

Ключевую функцию в «гданьском тексте» исполняют образы транспортных средств, например, в романе Вайзер Давидек это образ трамвая. В романе «Воспой сады», помимо телеги Бешка, знаковым видом транспорта является велосипед. Отец героя-рассказчика, даря сыну велосипед, неосознанно использует евангельский евхаристический парафраз: «Бери и поезжай, это свобода твоя» (Huelle 2014: 54) (ср.: «Приимите, ядите, сие есть Тело Мое» (Мф. 26: 26)). Примечателен тот же выбор немки Греты в другое историческое время, но в тех же топографических «координатах» Данцига-Гданьска («В товарном доме Шенфельдов она купила велосипед и с той поры каждое свободное время - по погоде - ездила на приморский променад» (Huelle 2014: 177)). Совпадение предметных деталей имеет символическое значение, намекая на родство душ пожилой немки и молодого поляка и играя роль связующего звена между хронотопами «польскости» и «немецкости» в романе Хюлле.

\section{3. Палимпсестное пространство города и экстерриториальный топос сада в романе П. Хюлле Воспой сады}

И. Е. Адельгейм дает следующую характеристику польской прозе о «возвращенных землях»: «Герой прозы о бывших немецких землях окружен не столько природой, сколько тканью самой Истории... Если в прозе о Восточных кресах история уничтожала миф, то здесь она сама предстает ее элементом, являя себя через палимпсестный характер пространства» (Адельгейм 2018: 51). В «гданьском тексте» Хюлле своеобразие палимпсеста проявляется в том, что за образом польского настоящего проступают «следы» немецкого прошлого, но за немецким слоем скрывается другой, еще более древний слой. Палимпсест в творчестве 
Хюлле выходит за рамки дуальности польское - немецкое и даже тернарности польское - кашубское - немецкое. В связи с полиэтничной и поликультурной палимпсестностью города автор пишет: «В Гданьске царила прекрасная, богатая, хотя и скученная разнородность» (Huelle 2016: 16). В романе Восnой сады Хюлле показывает, что Гданьск всегда был местом военных конфликтов между народами и государствами. В романе Хюлле в разных контекстах упоминаются: участие в войне за польское наследство XVIII века французов, тщетно пытавшихся помочь осажденному в Гданьске королю Станиславу Лещинскому; события шведского «потопа» XVII столетия, когда Гданьск стал для шведов городом бессмысленных жертв; нападение язычников-пруссов на Оливский монастырь в XIII веке. «Преданья старины глубокой» являются предметом рефлексии разных героев произведения - Эрнста Теодора, Бешка, героя-рассказчика, но центральное место в размышлениях большинства героев романа занимает роковой для Гданьска период тридцатых сороковых годов XX века.

В отличие от Стефана Хвина как автора романа Ханеман, образное видение города у Хюлле отличается вниманием к природной цикличности, противопоставленной исторической линейности. Это проявляется на примере романа Вайзер Давидек, в котором мифообразующую роль играет топос леса (Копцев - Мальцев 2018: 104). В анализируемом нами романе аналогичную роль играет топос сада, который, в отличие от леса, не является исключительно природным объектом. И. И. Свирида справедливо полагает, что сад находится «на пограничье природы и культуры» (Свирида 2009: 80).

Сад в романе Хюлле выступает символом освоения пространства. Невозможность возделывания сада воспринимается как симптом непреодолимой отчужденности переселенцев от заселяемых земель. По свидетельству рассказчика, его бабка Мария, живущая на юге Польши, объясняет свою невозможность переехать в Гданьск потребностью возделывать сад: «- Я не имела бы там сада. А сад, - сказала она, — это все, что у меня осталось» (Huelle 2014: 225). Признание бабки Марии перекликается с культом сада у Греты и Эрнста Теодора, выраженным цитатой из «Сонетов к Орфею» Рильке: «Воспой сады. Singe die Gärten» (Huelle 2014: 226). Таким образом, в сильно различающихся польском и немецком мироощущениях рассказчик находит общую для них философию сада, выраженную вольтеровой максимой из повести «Кандид»: «Надо возделывать свой сад».

Райско-идиллический топос романа Bocnoй сады имеет библейские аллюзии, совмещая буквальный и иносказательный смысл, выступая «производителем смыслов, постоянным мотивом священных книг» и сохраняя при этом «сакральную подоснову» (Свирида 2009: 80). Поэтому для молодого рассказчика сад — не только идиллическое место, 
но и топос эстетического и интеллектуального воспитания, таинственная «Книга», читаемая Гретой: «...если бы я сосчитал все свои визиты к пани Грете, если бы записывал их в календаре, каждую с конкретным днем и часом, было бы их целое множество, была бы Книга — не только ее и Эрнста Теодора, но и моя собственная, частная книга посвящения в тайну города и его улиц, мостовых, подворий, садов, переулков, трактиров, магазинов, была бы Книга моей жизни, которую я не написал, но аромат которой чувствовал за спиной, как запах цветущих лип» (Huelle 2014: 248).

И. И. Свирида выделяет два типа сада - «запертый», «заключенный», «отделенный от внешнего мира оградой» («hortus conclusus») и «пейзажный», «визуально слитый с окружающим ландшафтом» (Свирида 2009: 81). Исследовательница также подчеркивает, что первый традиционный тип сада связан с представлением о нем как о сакральном пространстве, второй отражает тенденцию «обмирщения» сада, проявившуюся в эпоху Просвещения (Свирида 2009: 91). Сад на Полянке, безусловно, относится к типу закрытого сада, несмотря на то, что, по сюжету, он был создан именно в эпоху Просвещения. Будучи местом любви Греты и Эрнста Теодора, сад выступает топосом чувственных, земных наслаждений. Однако в романе Хюлле сад как модель мира является не только райским топосом. Воплощая универсальный принцип палимпсеста, он представляет собой симбиоз райского и инфернального начала.

Образ инфернального сада раскрывается в жизнеописании первого владельца двора на Полянке Франсуа де Венанкурта, мемуары которого после трагической смерти отца Эрнста Теодора переходят в собственность последнего. Выходец из Бразилии, сын тиранического рабовладельца, Венанкурт совершает ряд жестоких убийств, первым из которых была его коварная расправа с отцом. В период добровольного затворничества в доме на Полянке Франсуа становится серийным убийцей, заманивая в дом жертв обеих полов, насилуя и лишая их жизни. По стечению романных обстоятельств, обнаружение кладбища жертв на дне садового пруда совпало с захватом вольного города Данциг гитлеровской Германией в 1939 г.

Эксцентричная биография Венанкурта соединяет локус ГданьскаОливы с бразильской фазендой отца героя и с Кронштадтской крепостью, в которой Венанкурт находился в качестве военнопленного. Следовательно, жизнеописание героя не только расширяет исторические горизонты повествования, но и создает прецедент экстерриториальности. Соответствующий термин ввел в отечественное литературоведение В. Б. Земсков, указывая, что понятие экстерриториальность обобщает «все варианты вненаходимости... по отношению к родному локусу и своей культуре» (Земсков 2015: 285). Исследователь разграничивает экстерриториальность эмпирическую («все формы... перемещения из своего пространства в чужое» (Земсков 2015: 285)) и трансэмпирическую («имагинативное пре- 
бывание писателя в чужом пространстве» (Земсков 2015: 285)). Генезис термина экстерриториальность исследователь связывает с культурой русского зарубежья, хотя независимо от нее к тому же понятию обратился Бруно Шульц в рассказе «Весна» (1937) (Шульц 2000: 190). У Шульца понятие экстерриториальности связано с изолированностью и засекреченностью места, следовательно, экстерриториальности соответствует «закрытый» сад («hortus conclusus»). И. И. Свирида пишет: «Понятие рая - огражденного сада - могло возникнуть в связи с представлением о грехопадении» (Свирида 2009: 89). Согласно библейской картине мира, первыми субъектами экстерриториальности были, безусловно, Адам и Ева, изгнанные из райского сада. Следуя заповеди о возделывании сада, Грета и Эрнст Теодор ведут замкнутый образ жизни в доме на Полянке, пытаясь уберечь свой участок земли от влияний внешнего мира, оказавшегося под властью демонической национал-социалистической идеологии. Однако автор романа показывает, как зло возрождается внутри самого сада, из мрака прошлого.

В пространстве романа Воспой сады есть инфернальный локус, образующий скрытую аналогию с садом Венанкурта - это здание анатомического института на улице Дельбрюкаллее (ныне Кюри-Склодовской), получившее мрачную известность как «дом профессора Шпаннера». Деятельность ученого-анатома, изготовлявшего по государственному заказу третьего рейха мыло из жира убитых людей, была с потрясающей проникновенностью описана в рассказе Зофьи Налковской «Профессор Шпаннер» из цикла Медальоны, предваряемого эпиграфом: «Люди людям уготовили эту судьбу» (Налковская 1979: 413). Внезапное появление Рудольфа Шпаннера в момент обнаружения останков жертв Венанкурта является знаменательным стечением обстоятельств в романе Хюлле, отражающим идею диалектического сопряжения случайного с закономерным («Моментально появился профессор Шпаннер из академии практической медицины, который три месяца спустя вступил в должность шефа института анатомии» (Huelle 2014: 276)). В конце повествования сообщается, что, будучи экспертом в «деле Венанкурта», Шпаннер «только по одному ему известной причине» решил «наложить покров государственной тайны» (Huelle 2014: 314) на следы преступления французского маньяка, жившего в далеком XVIII веке, но связанного, как и Шпаннер, с Данцигом. «Перемещение» из пространства документальной прозы Налковской в пространство вымышленной прозы Хюлле устанавливает связь между домами Шпаннера и Венанкурта как местами засекреченных преступлений, предпринятых из садистической жестокости их организаторов и исполнителей.

Трансэмпирическая (имагинативная) экстерриториальность проявляется вводом в повествование мотива сенсационной находки партитуры вагнеровской оперы «Крысолов из Гамельна». Идея переработки неиз- 
вестного произведения на современный лад (наряду с идеей музыкальной интерпретацией Дуинских элегий Рильке) преследует Эрнста Теодора на протяжении всего действия. В романном контексте средневековая легенда о крысолове исполняет функцию параболы: крысолов - это ловец и губитель душ, двойниками которого в тексте романа являются преступники Венанкурт и Шпаннер. В видении Эрнста Теодора крысолов является также аллегорическим воплощением фюрера, появление которого на политическом небосклоне находит фанатичную поддержку большинства немецкого народа, вызывая тревогу немногих инакомыслящих. Сокровенный смысл демонического образа крысолова обнаруживается в пророческих словах Эрнста Теодора: «Крысолов выведет нас из наших городов. Они сгорят. Обратятся в руины. Зарастут сорняками. Будет так. Вот увидишь» (Huelle 2014: 207).

Палимпсестность «гданьского текста» раскрывается через амбивалентный топос идиллическо-инфернального сада. Авторское стремление увидеть родной город как гармонический космос вступает в контраст с диагнозом хаотизации и эсхатологизации городского пространства. Следом за немецким филологом К. Гарбером, судьбу Данцига, как и Кёнигсберга, мы можем назвать «эмблемой апокалипсиса, вызванного рукой человека» (Гильманов - Мальцев 2018: 17).

\section{5. Заключение}

В итоге мы приходим к выводу, что «гданьский» роман Хюлле Bocnoŭ caдbl отражает попытку адаптации поколения, рожденного в послевоенном Гданьске, к пространству города, хранящего на себе печать поликультурной и полиэтнической истории. В отличие от представителей военного поколения, поколение рожденных в Гданьске не чувствует враждебности к немцам и настроено на то, чтобы преодолеть пропасть между довоенным Данцигом и послевоенным Гданьском. Сознавая необходимость преодоления отчужденности от довоенного прошлого, Хюлле ставит в центр повествования топос сада, смысл которого заключается в императиве возделывания природы, ее освоения, превращения хаоса в космос. Вместе с тем роман Воспой сады является манифестацией авторского пессимизма, проявляющегося в сомнении, способен ли человек дать верный ответ на вызов исторического зла в облике фашизма.

В художественном мировосприятии Хюлле сам Гданьск является «книгой», «текстом», «садом», требующим одновременно буквального и аллегорического восприятия. Картографическая достоверность городских описаний в романе Bocnoŭ cadbl сочетается с поэтикой условности, а интерес к истории города - с попыткой расшифровать метафизический и метаисторический смысл образа Данцига-Гданьска. 


\section{ЛИТЕРАТУРА}

Адельгейм Ирина. Психология поэтики: аутопсихотерапевтические функции художественного текста (на материале польской прозы 1990-2010-х г2.). М.: Индрик,2018.

Гильманов Владимир, Мальцев Леонид. Телеология начал в литературной судьбе Восточной Пруссии. Калининград: Издательство БФУ им. И. Канта, 2018.

Земсков Валерий. Образ России в современном мире и иные сюжеты. М. - СПб.: Центр гуманитарных инициатив; Гнозис, 2015.

Копцев Иван, Мальцев Леонид. «Эсхатология городского текста в романе П. Хюлле “Вайзер Давидек”». Балтийский гуманитарный журнал 7/ 3 (2018): 102-104.

Налковская Зофья. Избранное. М.: Художественная литература, 1979.

Свирида Инесса. Метаморфозы в пространстве культуры. М.: Индрик, 2009.

Шульц Бруно. Трактат о манекенах. Собрание прозы. СПб.: ИНАПРЕСС, 2000.

Huelle Paweł. Śpiewaj ogrody. Kraków: Znak, 2014.

Huelle Paweł, Szczepuła Barbara, «“Śpiewaj ogrody” to książka o miłości i muzyce». Dziennik Battycki. 2014. 30 stycznia. <http:// dziennikbaltycki.pl/pawel-huelle-spiewaj-ogrody -to-ksiazka-o-milosci-i-muzyce-muzyka-nadaje-rytm-erotyzmowi-rozmowa/ar/3316512> 10.01.2020.

Huelle Paweł. Ulica Świętego Ducha i inne historie. Kraków: Znak, 2016.

Olejniczak Józef. Arkadia i małe ojczyzny. Vincenz - Stempowski-Wittlin - Miłosz. Kraków: Oficyna Literacka, 1992.

Przybylski Ryszard Kazimierz. Wszystko inne. Szkice o literaturze i kulturze współczesnej. Poznań: Obserwator, 1994: 174-183.

Rybicka Elżbieta. Geopoetyka. Przestrzeń i miejsce we wspótczesnych teoriach i praktykach literackich. Kraków: Universitas, 2014.

Ziątek Zygmunt. «Sierpień — grudzień — historia. Od dokumentów czasu do literatury miejsca». Brodzka Alina, Burska Lidia (red.) Sporne sprawy polskiej literatury współczesnej. Warszawa: IBL PAN, 1998: 257-322.

\section{LITERATURA}

Adel'gejm Irina. Psihologiya poetiki: autopsihoterapevticheskie funkcii hudozhestvennogo teksta (na materiale pol'skoj prozy 1990-2010-h g.g.). M.: Indrik, 2018.

Gil'manov Vladimir, Mal'cev Leonid. Teleologiya nachal v literaturnoj sud'be Vostochnoj Prussii. Kaliningrad: Izdatel'stvo BFU im. I. Kanta, 2018.

Huelle Paweł. Śpiewaj ogrody. Kraków: Znak, 2014.

Huelle Paweł, Szczepuła Barbara, «“Śpiewaj ogrody” to książka o miłości i muzyce». Dziennik Battycki. 2014. 30 stycznia. <http:// dziennikbaltycki.pl/pawel-huelle-spiewaj-ogrody -to-ksiazka-o-milosci-i-muzyce-muzyka-nadaje-rytm-erotyzmowi-rozmowa/ar/3316512> 10.01.2020.

Huelle Paweł. Ulica Świętego Ducha i inne historie. Kraków: Znak, 2016.

Kopcev Ivan, Mal'cev Leonid. «Eskhatologiya gorodskogo teksta v romane P. Hyulle "Vajzer Davidek"». Baltijskij gumanitarnyj zhurnal 7/ 3 (2018): 102-104.

Nalkovskaya Zof'ya. Izbrannoe. M.: Hudozhestvennaya literatura, 1979.

Olejniczak Józef. Arkadia i małe ojczyzny. Vincenz - Stempowski - Wittlin - Miłosz. Kraków: Oficyna Literacka, 1992.

Przybylski Ryszard Kazimierz. Wszystko inne. Szkice o literaturze i kulturze współczesnej. Poznań: Obserwator, 1994: 174-183.

Rybicka Elżbieta. Geopoetyka. Przestrzeń i miejsce we współczesnych teoriach i praktykach literackich. Kraków: Universitas, 2014.

Shul'c Bruno. Traktat o manekenah. Sobranie prozy. SPb.: INAPRESS, 2000.

Svirida Inessa. Metamorfozy v prostranstve kul'tury. M.: Indrik, 2009. 
Zemskov Valerij. Obraz Rossii v sovremennom mire i inye syuzhety. M., SPb.: Centr gumanitarnyh iniciativ; Gnozis, 2015.

Ziątek Zygmunt. "Sierpień — grudzień — historia. Od dokumentów czasu do literatury miejsca». Brodzka Alina, Burska Lidia (red.) Sporne sprawy polskiej literatury współczesnej. Warszawa: IBL PAN, 1998: 257-322.

Владимир Гиљманов, Леонид Маљцев

МЕТАФИЗИКА ГРАДСКОГ ПРОСТОРА

У РОМАНУ П. ХИЛЕА ОПЕВАJ ВРТОВЕ

\section{Резиме}

У члланку се анализира уметнилки простор „гдањског текста“ на примеру романа Павла Хилеа Опевај вртове. У чланку се даје потврда да проучавани роман припада правцу „локалних домовина“ у пољској књижевносит. Показан је значај мапе пејзажа као основног инструмента конструисања уметничког простора. Дефинише се систем локуса града са аспекта супротстваљања „пољског“ и „немачког“ Гдањска - Данцига и просторног изражавања овог историсјког конфликта. Подвлачи се такође значај фактора националног идентитета Кашупа у уметничком представљању градског простора. У вези с овим примећује се да палимпсестна организација градског текста Хулеа излази изван овира опозиције пољско - немачко и базира се на представама о полиетничности и поликултуралости Гдањска, у чијој су историји важну улогу играли Кашупи, Пруси и многи други народи. Долази се до закључка да је централни митотворачки топос-симбол приповедања врт, чији смисао је у обрађивању и освајању природе, превазилажењу отуђености простора. С друге стране, истиче се да врт у роману Хилеа има амбивалентну природу, будући да није само топос стварања него и топос апокалипсе.

Кључне речи: Хиле, простор, град, „гдањски текст“, мапа, топос врта, палимпсест, екстерироријалност. 